\title{
HEINRICH MASCHKE.
}

\section{Resolutions on the Death of Professor Heinrich MaschKe.}

Whereas, in the death of Professor Heinrich Maschke the Chicago Section of the American Mathematical Society suffers the loss of one of its most honored, influential, and beloved members, the undersigned committee appointed by the Section hereby expresses its deep appreciation of the services and character of Professor Maschke.

From the first organization of the Chicago Section until the present session Professor Maschke has been one of its most active and inspiring members. By his genial qualities, his unusual sympathy as a teacher, his integrity and intellectual honesty, he has won and held the affection of those who have known him. By his ability as an investigator he has contributed greatly to the development of productive mathematical scholarship in the formative period of the Society, and in his own person he has exemplified the influence of German scholarship which has contributed so potently to this development. In the death of Professor Maschke the Section for the first time feels the loss of one of its leaders.

The committee recommends that this resolution be incorporated in the records of the Section and that a copy be transmitted to Mrs. Maschke as an expression of our sympathy in her deep loss. 